\title{
KOMPENSASI DAN MOTIVASI KERJA PENGARUHNYA TERHADAP KINERJA KARYAWAN MELALUI KEPUASAN KERJA SEBAGAI VARIABEL INTERVENING
}

\author{
${ }^{1}$ Muhamad Rifa'i, ${ }^{2}$ Rosalia Sela, ${ }^{3}$ Rr Nugraheni Suci Sayekti \\ Universitas Tribhuwana Tunggadewi Malang \\ Email: rifaiunitri@gmail.com
}

\begin{abstract}
This study empirically tested the effect of compensation and work motivation on employee performance directly or indirectly mediated by job satisfaction as intervening variables. This research uses a quantitative approach. Data is primary data collected using questionnaires. The data is analyzed using a path analysis model using the SmartPLS program. The results of the study showed that partial compensation has a significant and positive influence on job satisfaction Work motivation has a significant positive influence on job satisfaction Compensation has no influence on employee performance. Work motivation has no effect on employee performance. Job satisfaction has a significant and positive influence on employee performance. Compensation has an insorant and positive effect on employee performance through job satisfaction. Work motivation has a significant and positive effect on employee performance that is mediated by job satisfaction.
\end{abstract}

Keywords: Compensation, Job Motivation, Job Satisfaction and Employee Performance.

\begin{abstract}
ABSTRAK
Penelitian ini menguji secara empiris pengaruh kompensasi dan motivasi kerja terhadap kinerja karyawan secara langsung maupun secara tidak langsung yang dimediasi oleh kepuasan kerja sebagai variabel intervening. Penelitian ini menggunakan pendekatan kuantitatif. Data merupakan data primer yang dikumpulkan menggunakan kuesioner. Data dianalisis menggunakan model path analysis menggunakan program Smart-PLS. Hasil penelitian menunjukkan kompensasi secara parsial mempunyai pengaruh signifikan dan positif terhadap kepuasan kerja Motivasi kerja memiliki pengaruh positif signifikan terhadap kepuasan kerja Kompensasi tidak memiliki pengaruh pada kinerja karyawan. Motivasi kerja tidak berpengaruh terhadap kinerja karyawan. Kepuasan kerja memiliki pengaruh signifikan dan positif terhadap kinerja karyawan. Kompensasi berpengaruh tidak signifikan dan positif pada kinerja karyawan melalui kepuasan kerja. Motivasi kerja berpengaruh signifikan dan positif terhadap kinerja karyawan yang dimediasikan oleh kepuasan kerja.
\end{abstract}

Kata Kunci: Kompensasi, Motivasi Kerja, Kepuasan Kerja dan Kinerja Karyawan. 


\section{PENDAHULUAN}

Kerhasilan suatu perusahaan sangat dipengaruhi oleh peranan anggota yang berada dalam perusahaan tersebut. Salah satu unsur penting dalam suatu perusahaan adalah sumber daya manusia yang dapat menentukan keberhasilan perusahaan, karena manusia merupakan individu yang selalu berpikir, merasakan, berkeperluan, dan berekspektasi tertentu yang dapat memicu produktivitas perusahaan. Kinerja karyawan sangat diperlukan guna meningkatkan produktivitas perusahaan, (Foster, 2011) kinerja karyawan sangat menentukan terhadap perusahaan karena mereka dituntut untuk melaksanakan tugasnya dengan penuh tanggung jawab sehingga kinerja karyawan sangat penting untuk dipertahankan.

Terdapat banyak faktor yang dapat mempengaruhi kinerja karyawan, salah satunya adalah kompensasi (Hameed, Ramzan, Zubair, Ali, \& Arslan, 214). Penelitian (Bawoleh,, Sifrid, Pangemanan, \& Tielung, 2015) dan (Damayanti, Susilaningsih, \& Sumaryati, 2013) yang menyatakan motivasi berhubungan positif dengan kepuasan kerja. Motivasi juga memiliki peran yang sangat penting untuk meningkatkan kinerja karyawan, motivasi berpengaruh terhadap kinerja karyawan (Seniwoliba \& Nchorbuno, 2013).. Motivasi karyawan merupakan suatu bentuk kesediaan untuk berusaha keras mencapai tujuan organisasi dengan memperhatikan usaha untuk memenuhi beberapa kebutuhan, serta upaya untuk memperbaiki dan membentuk pengetahuan, sikap, dan perilaku karyawan sehingga karyawan tersebut secara sukarela berusaha bekerja secara kooperatif dengan para karyawan lainnya untuk meningkatkan kinerjanya (Amianti \& Supriyanto, 2012). Motivasi yang tepat dan baik dapat meningkatkan dan menumbuhkan semangat kerja karyawan, sehingga menambah semangat dalam bekerja, maka dengan demikian akan tercapai kinerja karyawan yang tinggi.

Hasil dari penelitian (Komara \& Nelliwati, 2014), dan (Lusiana, Anggraini, \& Arina, 2015) menunjukkan kompensasi berpengaruh terhadap kinerja karyawan melalui mediasi kepuasan kerja. Melalui penelitian ini menunjukkan bahwa terdapat hubungan secara tidak langsung antara kompensasi melalui kepuasan kerja terhadap kinerja karyawan. Hasil penelitian (Supatmi, Nimran, \& Utami, 2013) yang mempunyai hasil sama yaitu adanya pengaruh kepuasan kerja terhadap kinerja. Jika karyawan merasa puas, maka karyawan tersebut memiliki sikap positif dan bangga terhadap pekerjaan 
nya. Selain itu, karyawan juga menilai tinggi pekerjaannya karena merasa situasi dan kondisi kerjanya dapat memenuhi kebutuhan, keinginan dan harapan. Karyawan yang memiliki rasa puas di dalam bekerja akan lebih produktif dalam bekerja.

\section{LANDASAN TORI}

\section{Kinerja Karyawan}

Kinerja adalah suatu hasil yang dapat diukur dengan efektifitas dan efisiensi suatu pekerjaan yang dilakukan oleh sumber daya manusia atau sumber daya lainnya dalam pencapaian tujuan atau sasaran perusahaan dengan baik dan berdaya guna. Menurut (Foster, 2011) kinerja karyawan sangat berpengaruh terhadap perusahaan karena mereka dituntut untuk melaksanakan tugas mereka dengan penuh tanggung jawab. Kualitas sumber daya manusia memiliki manfaat ditinjau dari pengembangan sumber daya perusahaan yaitu perbaikan kinerja, penyesuaian kompensasi, keputusan penempatan, kebutuhan pelatihan, perencanaan dan pengembangan karir, efisiensi proses penetapan staf dan kesempatan kerja yang sama.

\section{Kompensasi}

Kompensasi adalah semua pendapatan yang berbentuk uang, barang langsung atau tidak langsung yang diterima karyawan sebagai imbalan atas jasa yang diberikan kepada perusahaan (Hasibuan S. P., 2014). Sedangkan menurut (Swasto, 2011) kompensasi ditinjau dari sudut individu karyawan adalah segala sesuatu yang diterima karyawan sebagai balas jasa atas kontribusi tenaga dan pikiran yang telah karyawan sebagai tanda balas jasa karena telah memberikan sumbangan kontribusi tenaga maupun pikiran terhadap organisasi tempat bekerja mereka. Kompensasi adalah keseluruhan imbalan yang diterima oleh karyawan sebagai penghargaan atas kontribusi yang diberikan kepada perusahaan, baik yang bersifat finansial maupun non finansial (Supriyadi, 2015).

\section{Motivasi Kerja}

Motivasi adalah pemberian daya seseorang yang menciptakan kegairahan seseorang agar mereka mau bekerja sama, bekerja efektif dan terintegrasi dengan segala 
daya upayanya untuk mencapai kepuasan (Hasibuan S. , 2016). Motivasi adalah kondisi atau energi yang menggerakan diri karyawan yang terarah atau tertuju untuk mencapai tujuan organisasi perusahaan. Motivasi adalah suatu keadaan dalam pribadi yang mendorong keinginan individu untuk melakukan keinginan tertentu guna mencapai tujuan (Handoko, 2014). Menurut (Hasibuan S. P., 2014) bahwa motivasi kerja mengacu pada teori Maslow dipengaruhi oleh upaya memenuhi kebutuhan berupa kebutuhan fisik, kebutuhan akan keamanan dan keselamatan, kebutuhan sosial kebutuhan akan penghargaan diri, dan kebutuhan perwujudan diri.

\section{Kepuasan Kerja}

Kepuasan kerja merupakan merupakan evaluasi yang menggambarkan seseorang atas perasaan sikapnya senang atau tidak senang, puas atau tidak puas dalam bekerja (Rivai \& Sagala, 2011). Kepuasan kerja menjadi masalah yang cukup menarik dan penting, karena terbukti besar manfaatnya bagi kepentingan individu, industri dan masyarakat (Sutrisno, 2016). Kepuasan kerja seorang pegawai dapat merasakan pekerjaan menyenangkan atau tidak menyenangkan untuk dikerjakan (Bangun, 2012), pada dasarnya teori-teori tentang kepuasan kerja yang lazim dikenal ada tiga macam yaitu: teori ketidaksesuaian (discrepancy theory), teori keadilan (equity theory), dan teori dua faktor (two factor theory) (Rivai \& Sagala, 2011).

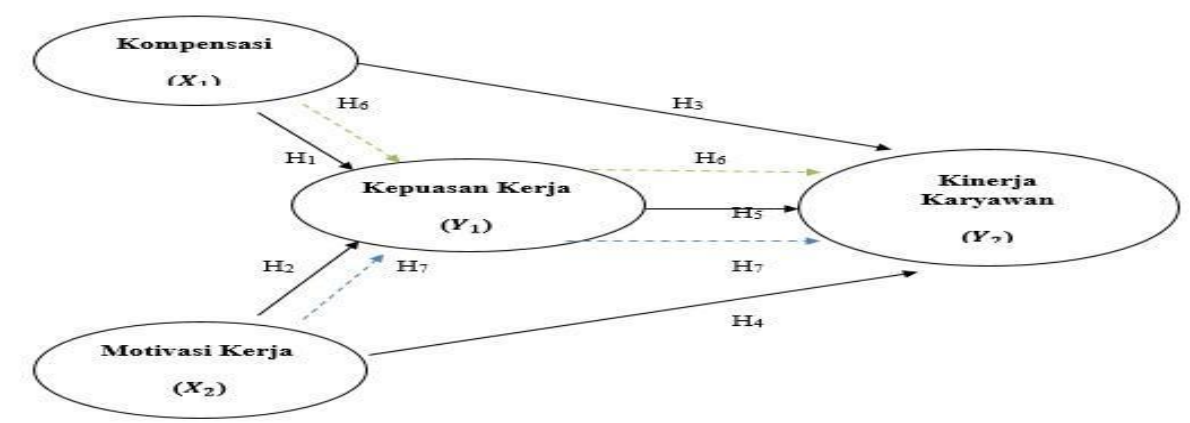

Gambar 1.

Kerangka

pikir

Penelitian

\section{Hipotesis}

Diduga kompensasi berpengaruh terhadap kepuasan kerja karyawan.

Diduga motivasi kerja berpengaruh terhadap kepuasan kerja karyawan.

Diduga kompensasi berpengaruh terhadap kinerja karyawan.

Diduga motivasi kerja berpengaruh terhadap kinerja karyawan. 
Diduga kepuasan kerja berpengaruh terhadap kinerja karyawan.

Diduga kompensasi berpengaruh terhadap kinerja karyawan melalui kepuasan kerja.

Diduga motivasi kerja berpengaruh terhadap kinerja karyawan melalui kepuasan kerja.

\section{METODE PENELITIAN}

Penelitian ini dilakukan terhadap karyawan di PT. Magnum Attack Malang Jawa Timur yang sedang berupaya mendorong kinerja karyawan yang terdampak akibat pandemi covid-19. Untuk memahami kinerja karyawan maka dalam penelitian ini dianalisis pengaruh kompensasi, dan motivasi kerja terhadap kinerja karyawan dengan kepuasan kerja sebagai variabel intervening pada perusahaan tersebut. Penelitian ini menggunakan pendekatan kuantitatif dengan sumber data primer dan sekunder. Sampel ini mengambil seluruh anggota populasi menggunakan sensus karena jumlah populasi dengan penelitian ini termasuk kecil yaitu 36 responden. Teknik pengumpulan data dilakukan dengan observasi, interview, dokumentasi, dan kuesioner. Variabel penelitian yang diamati adalah kompensasi (X1), Motivasi (X2), Kepuasan Kerja (Y1), dan Kinerja Karyawan (Y2).

Pengujian penelitian ini menggunakan analisis jalur (path analysis), yang merupakan perluasan dari analisis regresi linear berganda. Analisis dilakukan sebanyak dua tahap. Analisis tahap pertama untuk mengetahui kekuatan hubungan dari variabel bebas (independen) terhadap variabel mediasi (intervening), analisis tahap kedua untuk mengetahui kekuatan hubungan dari variabel bebas (independen) terhadap variabel terikat (dependent).

\section{PEMBAHASAN}

Penelitian ini menguji tujuh hipotesis yang dianalisis dengan menggunakan analisis jalur yang merupakan perluasan dari analisis regresi untuk mengukur hubungan antar variabel dependen dengan independen yang telah ditetapkan dalam tujuan penelitian berdasarkan kajian teori dan penelitian terdahulu. Pengujian hipotesis dalam penelitian ini menggunakan analisis jalur yang hasilnya sebagai berikut: 


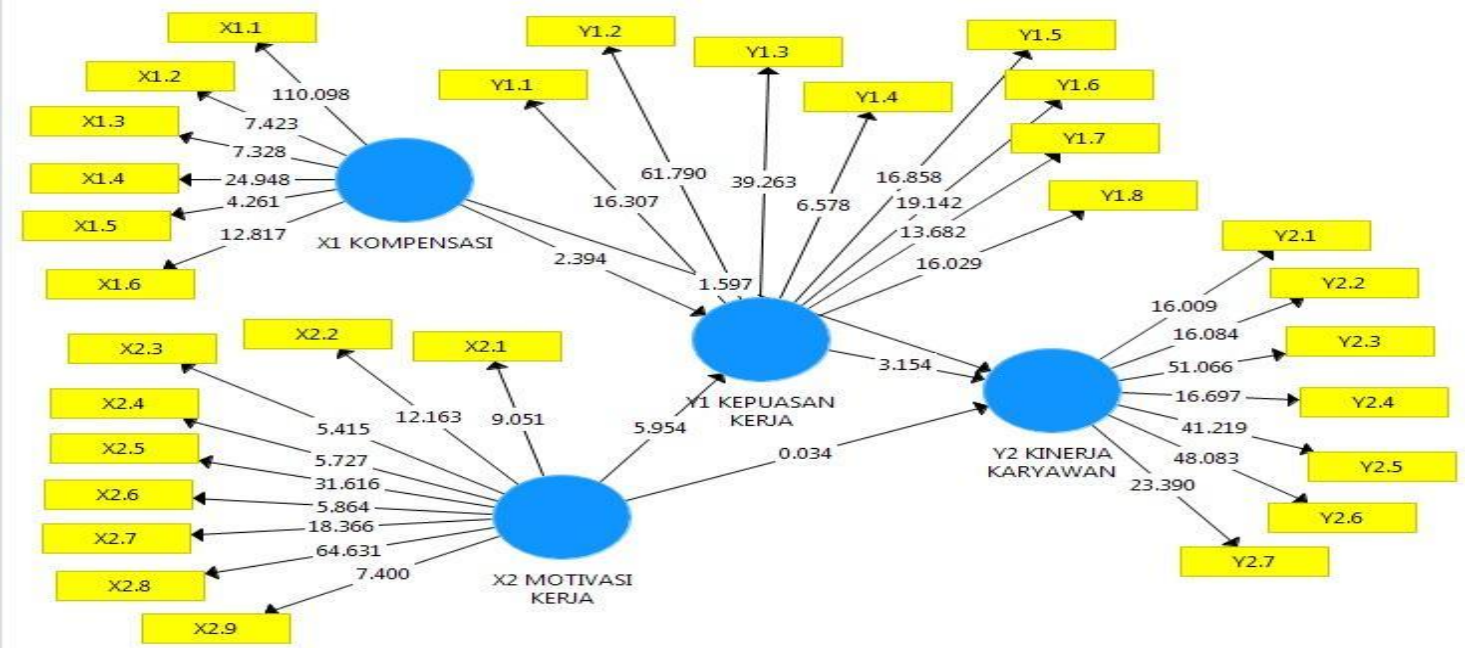

Sumber: Hasil olah data dengan Smart-PLS (2020)

Gambar 2. Model Pengukuran Pengujian

Selanjutnya dilakukan uji hubungan antar variabel penelitian untuk menjawab hipotesis penelitian yanh hasilnya ditampilkan pada tabel 1 sebagai berikut:

Tabel 1. Path Coefficient

\begin{tabular}{|c|c|c|c|c|c|c|}
\hline Konstruk & & $\begin{array}{l}\text { Original } \\
\text { Sample }(\mathrm{O})\end{array}$ & $\begin{array}{l}\text { Sample } \\
\text { Mean } \\
(\mathrm{M})\end{array}$ & $\begin{array}{l}\text { Standard } \\
\text { Deviation } \\
\text { (STDEV) }\end{array}$ & $\begin{array}{l}\text { T Statistics } \\
(|\mathrm{O} / \mathrm{STDEV}|)\end{array}$ & P Values \\
\hline X1 Kompensasi & $->\quad \mathrm{Y} 1$ & 0,286 & 0,303 & 0,114 & 2,510 & 0,012 \\
\hline Kepuasan Kerja & & & & & & \\
\hline $\begin{array}{l}\text { X2 Motivasi Kerja } \\
\text { Kepuasan Kerja }\end{array}$ & $->\quad Y 1$ & 0,708 & 0,683 & 0,119 & 5,954 & 0,000 \\
\hline $\begin{array}{l}\text { X1 Kompensasi ->Y2 } \\
\text { Karyawan }\end{array}$ & Kinerja & 0,242 & 0,222 & 0,158 & 1,537 & 0,125 \\
\hline $\begin{array}{l}\text { X2 Motivasi Kerja -> Y2 } \\
\text { Karyawan }\end{array}$ & Kinerja & 0,007 & 0,021 & 0,233 & 0,031 & 0,975 \\
\hline $\begin{array}{l}\text { Y1 Kepuasan Kerja } \\
\text { Kinerja Karyawan }\end{array}$ & $\rightarrow \quad \mathrm{Y} 2$ & 0,736 & 0,741 & 0,223 & 3,301 & 0,001 \\
\hline
\end{tabular}

Sumber: Hasil Olah Data dengan Smart-PLS (2020)

Berdasarkan tabel 1 konstruk kompensasi mempunyai pengaruh $(\mathrm{O}=0.286)$ dengan konstruk kepuasan kerja. Nilai t - statistic pada hubungan konstruk ini adalah $2,510>$ t-tabel 2,035 dan nilai $\mathrm{p}$ - value $0,012<$ standard error 0,05 . Sehingga kompensasi berpengaruh positif signifikan terhadap kepuasan kerja, sehingga hipotesis 
pertama Diterima. Konstruk motivasi kerja mempunyai pengaruh $(\mathrm{O}=0,708)$ dengan konstruk kepuasan kerja. Nilai t - statistic pada hubungan konstruk ini adalah 5,954 > ttabel 2,035 dan nilai $\mathrm{p}$ - value $0,000<$ standard error 0,05 . Sehingga motivasi kerja berpengaruh positif signifikan terhadap kepuasan kerja, sehingga hipotesis kedua diterima. Konstruk kompensasi tidak mempunyai pengaruh $(O=0,242)$ dengan konstruk kinerja karyawan. Nilai t-statistic pada hubungan konstruk ini adalah 1,537 < t-tabel 2,035 dan nilai $\mathrm{p}$ - value 0,125 > standard error 0,05. Sehingga kompensasi tidak berpengaruh terhadap kinerja karyawan, sehingga hipotesis ketiga ditolak. Konstruk motivasi kerja tidak mempunyai pengaruh $(\mathrm{O}=0,007)$ dengan konstruk kinerja karyawan. Nilai t-statistic pada hubungan konstruk ini adalah 0,031 < t-tabel 2,035 dan nilai $\mathrm{p}$ - value $0,975>$ standard error 0,05 . Sehingga motivasi kerja tidak berpengaruh terhadap kinerja karyawan, sehingga hipotesis keempat ditolak. Konstruk kepuasan kerja mempunyai pengaruh $(\mathrm{O}=0,736)$ dengan konstruk kinerja karyawan. Nilai $\mathrm{t}-$ statistic pada hubungan konstruk ini adalah 3,301 > t-tabel 2,035 dan nilai $\mathrm{p}$ - value 0,001 < standard error 0,05 . Sehingga kepuasan kerja berpengaruh positif signifikan terhadap kinerja karyawan, sehingga hipotesis kelima diterima.

Untuk menguji hipotesis keenam dan ketujuh yang melibatkan variabel intervening sehingga diuji dengan analisis path analysis dengan efek mediasi atau intervening, yaitu hubungan antara konstruk eksogen dan endogen melalui variabel penghubung. Dengan kata lain, pengaruh variabel eksogen terhadap variabel endogen bisa secara langsung tetapi juga bisa melalui variabel penghubung atau intervening yang hasil analisisnya dapat di lihat pada tabel 2 sebagai berikut:

Tabel 2. Total Effect

\begin{tabular}{llllll}
\hline Konstruk & $\begin{array}{l}\text { Original } \\
\text { Sample } \\
(\mathrm{O})\end{array}$ & $\begin{array}{l}\text { Sample } \\
\text { Mean } \\
(\mathrm{M})\end{array}$ & $\begin{array}{l}\text { Standard } \\
\text { Deviation } \\
(\text { STDEV })\end{array}$ & $\begin{array}{l}\text { T } \\
(\mid \mathrm{O} / \text { STDEV })\end{array}$ & P Values \\
\hline $\begin{array}{l}\text { Y1 Kepuasan Kerja -> Y2 Kinerja } \\
\text { Karyawan } \\
\text { X1 Kompensasi -> Y1 Kepuasan }\end{array}$ & 0,736 & 0,710 & 0,241 & 3,053 & 0,002 \\
$\begin{array}{l}\text { Kerja } \\
\text { X1 Kompensasi -> Y2 Kinerja }\end{array}$ & 0,452 & 0,453 & 0,185 & 2,441 & 0,020 \\
$\begin{array}{l}\text { Karyawan } \\
\text { X2 Motivasi Kerja -> Y1 Kepuasan }\end{array}$ & 0,708 & 0,684 & 0,121 & 5,841 & 0,015 \\
$\begin{array}{l}\text { Kerja } \\
\text { X2 Motivasi Kerja -> Y2 Kinerja }\end{array}$ & 0,528 & 0,527 & 0,183 & 2,891 & 0,000 \\
Karyawan
\end{tabular}


Sumber: Hasil Olah Data dengan Smart-PLS (2020)

Hasil dari analisis PLS tabel 3 menunjukan kompensasi mempunyai pengaruh positif signifikan $(\mathrm{O}=0,452)$ terhadap kinerja karyawan dengan nilai $\mathrm{t}$ - statistic 2,441 $>$ t-tabel 2,035. Kompensasi mempunyai pengaruh positif signifikan terhadap kepuasan kerja $(\mathrm{O}=0,286)$ dengan nilai $\mathrm{t}-$ statistic 2,341 > t-tabel 2,035. Kepuasan kerja mempunyai pengaruh positif yang signifikan terhadap kinerja karyawan $(\mathrm{O}=0,736)$ dengan nilai $\mathrm{t}-$ statistic 3,053 > t-tabel 2,035. Sehingga dapat dinyatakan bahwa kompensasi berpengaruh positif signifikan terhadap kinerja karyawan dengan kepuasan kerja sebagai variabel intervening, sehingga hipotesis keenam diterima. Motivasi kerja mempunyai pengaruh positif signifikan $(\mathrm{O}=0,528)$ terhadap kinerja karyawan dengan nilai $\mathrm{t}$ - statistic 2,891 > t-tabel 2,035.

Motivasi kerja mempunyai pengaruh positif signifikan terhadap kepuasan kerja $(\mathrm{O}=0,708)$ dengan nilai $\mathrm{t}$ - statistic 5,841 > t-tabel 2,035. Motivasi kerja mempunyai pengaruh positif yang signifikan terhadap kinerja karyawan $(\mathrm{O}=0,736)$ dengan nilai $\mathrm{t}-$ statistic 3,053>t-tabel 2,035. Sehingga dapat dinyatakan bahwa motivasi kerja berpengaruh positif signifikan terhadap kinerja karyawan dengan kepuasan kerja sebagai variabel intervening, sehingga hipotesis ketujuh diterima. Untuk mengetahui seberapa jauh variabel kepuasan kerja bisa memediasi hubungan antara kompensasi dan motivasi kerja terhadap kinerja karyawan dapat dilihat pada tabel specific indirect effects.

Tabel 3. Specific Indirect Effects

\begin{tabular}{llllll}
\hline Konstruk & $\begin{array}{l}\text { Original } \\
\text { Sample } \\
(\mathrm{O})\end{array}$ & $\begin{array}{l}\text { Sample } \\
\text { Mean }(\mathrm{M})\end{array}$ & $\begin{array}{l}\text { Standard } \\
\text { Deviation } \\
(\text { STDEV })\end{array}$ & $\begin{array}{l}\text { T } \\
(\mid \mathrm{O} / \text { STDEV|) }\end{array}$ & $\begin{array}{c}\text { Statistics } \\
\text { P Values }\end{array}$ \\
\hline $\begin{array}{l}\text { X1 Kompensasi -> Y1 Kepuasan } \\
\text { Kerja -> Y2 Kinerja Karyawan }\end{array}$ & 0,210 & 0,224 & 0,115 & 1,826 & 0,068 \\
X2 Motivasi Kerja -> Y1 & 0,521 & 0,482 & 0,181 & 2,881 & 0,004 \\
$\begin{array}{l}\text { Kepuasan Kerja }->\text { Y2 Kinerja } \\
\text { Karyawan }\end{array}$ & & & & & \\
\hline
\end{tabular}

Sumber: Hasil Olah Data dengan Smart-PLS (2020)

Berdasarkan tabel 3 menunjukan hubungan kompensasi terhadap kinerja 
karyawan yang dimediasi oleh kepuasan kerja tidak signifikan dengan nilai t-statistic $1,826<\mathrm{t}$-tabel 2,035, dan dengan nilai original sampel 0,210, hal ini berarti bahwa kepuasan kerja berperan sebagai partial control yang berarti untuk mengetahui hubungan antar variabel terdapat hubungan langsung seperti kompensasi terhadap kinerja begitu juga dengan motivasi terhadap kinerja dan yang tidak langsung seperti kompensasi terhadap kinerja melalui kepuasan kerja bagi juga dengan motivasi terhadap kinerja melalui kepuasan kerja. Begitu juga dengan hubungan motivasi kerja terhadap kinerja karyawan yang dimediasi oleh kepuasan kerja dinyatakan signifikan dengan nilai $\mathrm{t}$ - statistic 2,881 >2,035, dan dengan nilai original sampel sebesar 0,520 hal ini juga berarti bahwa kepuasan kerja berperan sebagai partial control dalam hubungan motivasi kerja terhadap kinerja karyawan (Garson, 2016).

\section{Pengaruh kompensasi terhadap kepuasan kerja karyawan}

Berdasarkan hasil penelitian menujukkan kompensasi berpengaruh terhadap kepuasan kerja sehingga kompensasi berpengaruh positif signifikan terhadap kepuasan kerja. Hasil penelitian ini menunjukan adanya dampak langsung dari kompensasi yang diberikan perusahaan kepada karyawan terhadap pencapaian kepuasan kerja karyawan. Karyawan merasa puas karena gaji, insentif dan tunjangan yang diberikan sesuai dengan pekerjaan dan kebutuhan. Hasil penelitian ini sejalan dengan (Bawoleh,, Sifrid, Pangemanan, \& Tielung, 2015) dan (Komara \& Nelliwati, 2014) yang menyatakan bahwa kompensasi berpengaruh terhadap kepuasan kerja.

\section{Pengaruh motivasi kerja terhadap kepuasan kerja karyawan}

Hasil penelitian menujukkan motivasi kerja mempunyai pengaruh terhadap kepuasan kerja sehingga motivasi kerja berpengaruh positif signifikan terhadap kepuasan kerja. Hasil penelitian tersebut, dikarenakan adanya dampak langsung dari motivasi kerja yang diberikan perusahaan pada karyawan terhadap pencapaian kepuasan kerja karyawan. Perusahaan memotivasi karyawan dengan memberikan gaji dan tunjangan yang sesuai dengan pekerjaan yang dilakukan, artinya semakin baik kualitas kerja maka perusahaan juga akan memberikan kompensasi yang lebih baik terhadap karyawannya. Hal tersebut membuat karyawan merasa puas terhadap apa yang 
dikerjakan karena perusahaan menjanjikan kompensasi yang sesuai dengan apa yang dikerjaan dan perusahaan mampu menepati untuk memberikan hal tersebut. Kemudian, lingkungan kerja yang nyaman dan kondusif juga mendorong karyawan untuk lebih semangat dalam bekerja. Hasil penelitian ini sejalan dengan penelitian (Bawoleh,, Sifrid, Pangemanan, \& Tielung, 2015) dan (Damayanti, Susilaningsih, \& Sumaryati, 2013) yang menyatakan bahwa motivasi berhubungan positif dengan kepuasan kerja.

\section{Pengaruh kompensasi terhadap kinerja karyawan}

Hasil penelitian menujukkan kompensasi tidak mempunyai pengaruh terhadap kinerja karyawan, sehingga hipotesis ketiga ditolak. Hasil ini dikarenakan kecilnya kompensasi yang diberikan tidak berpengaruh secara langsung terhadap kinerja karyawan. Hasil ini selanjutnya dikonfirmasi dengan pihak manajemen yang menjelaskan perusahaan sudah memberikan gaji yang sesuai dengan upah minimum kabupaten / kota, kemudian juga memberikan insentif untuk karyawan yang mampu mengejar target yang diberikan, dan memberikan bonus atas pencapaian tertentu, namun kenyataanya kinerja karyawan masih belum begitu stabil.

Selama ini faktor yang mempengaruhi kinerja karyawan adalah pengawasan dan pendekatan dari atasan secara khusus kepada karyawannya, sehingga bukan kompensasi yang bisa meningkatkan kinerja karyawan namun pengawasan dan pendekatan langsung dari manajer kepada karyawan yang dapat membuat karyawan menjadi lebih disiplin dan mengurangi terjadinya kesalahan. Hasil penelitian ini sejalan dengan (Riyadi, 2011) dan (Puspitasari, Nursyamsi, \& Rasjid , 2018) menunjukan kompensasi berpengaruh negatif terhadap kinerja karyawan. Besar kecilnya kompensasi yang diterima tidak berpengaruh pada kinerja.

\section{Pengaruh motivasi kerja terhadap kinerja karyawan}

Hasil penelitian menunjukkan motivasi kerja tidak mempunyai pengaruh dengan konstruk kinerja karyawan, sehingga hipotesis keempat ditolak. Dengan pemberian motivasi kerja yang baik, juga tidak menjamin karyawan tidak pernah mengeluh terhadap pekerjaan yang dilakukan. Itu artinya kinerja karyawan belum bisa meningkat dikarenakan motivasi yang diberikan masih secara umum, belum terlalu spesifik kepada 
masing-masing individu. Sehingga yang menentukan kinerja masing-masing individu bukan motivasi kerja yang diberikan oleh perusahaan, namun lebih tepatnya terletak pada motivasi dari diri individu karyawan tersebut. Hasil penelitian ini sejalan dengan penelitian (Murti \& Srimulyani, 2013) serta (Maheswari \& Lutvy, 2015) yang menunjukan motivasi tidak berpengaruh terhadap kinerja karyawan. Semakin tinggi motivasi kerja belum tentu akan mengakibatkan semakin tinggi pula kinerja karyawan. Seorang karyawan akan memiliki kinerja yang baik, jika memiliki keinginan, harapan, kebutuhan, tujuan sasaran, dorongan dan insentif yang didukung dengan kemampuan kerja yang baik.

\section{Pengaruh kepuasan kerja terhadap kinerja karyawan}

Hasil penelitian menunjukkan kepuasan kerja mempunyai pengaruh terhadap kinerja karyawan sehingga kepuasan kerja berpengaruh positif signifikan terhadap kinerja karyawan sehingga hipotesis diterima. Hasil ini dikarenakan adanya dampak langsung dari kepuasan kerja yang diperoleh karyawan terhadap kinerja karyawan. Semakin tinggi tingkat pencapaian kepuasan kerja karyawan maka semakin tinggi pula tingkat kinerja karyawan pada perusahaan tersebut. Hasil dari penelitian ini sejalan dengan penelitian (Supatmi, Nimran, \& Utami, 2013) yang mempunyai hasil sama yaitu adanya pengaruh kepuasan kerja terhadap kinerja. Jika karyawan merasa puas, maka karyawan tersebut memiliki sikap positif dan bangga terhadap pekerjaannya. Selain itu, karyawan juga menilai tinggi pekerjaannya karena merasa situasi dan kondisi kerjanya dapat memenuhi kebutuhan, keinginan dan harapan. Karyawan yang memiliki rasa puas di dalam bekerja akan lebih produktif dalam bekerja.

\section{Pengaruh kompensasi terhadap kinerja karyawan melalui kepuasan kerja}

Hasil penelitian menunjukkan kompensasi mempunyai pengaruh positif signifikan terhadap kinerja karyawan dengan kepuasan kerja sebagai variabel intervening sehingga hipotesis diterima. Hubungan kompensasi terhadap kinerja karyawan yang dimediasi oleh kepuasan kerja namun tidak signifikan, hal ini berarti bahwa kepuasan kerja berperan sebagai partial control. Partial control berarti bahwa dalam hubungan antar variabel terdapat hubungan langsung dan tidak langsung (Garson, 
2016). Hasil penelitian menujukkan kompensasi tidak bisa membawa dampak langsung terhadap kinerja karyawan, namun kompensasi akan membawa pengaruh langsung terhadap kepuasan kerja. Kemudian kepuasan kerja karyawan yang dihasilkan dari pemberian kompensasi yang baik akan dapat meningkatkan kinerja karyawan. Pemberian gaji, tunjangan dan insentif yang sesuai dengan apa yang dikerjakan karyawan akan membuat karyawan merasa puas, kemudian kepuasan yang diperoleh tersebut membuat karyawan untuk lebih terpacu untuk lebih disiplin, lebih berkualitas dalam bekerja, lebih teliti dan berusaha untuk bisa bekerja sama dengan rekan kerja lainya. Sehingga untuk memperoleh kinerja karyawan yang maksimal perusahaan harus bisa mencapai kepuasan kerja karyawan melalui pemberian kompensasi yang sesuai. Hasil penelitian ini sejalan dengan penelitian (Komara \& Nelliwati, 2014) dan (Lusiana, Anggraini, \& Arina, 2015) yang menyaakan kompensasi berpengaruh terhadap kinerja karyawan melalui mediasi kepuasan kerja. Melalui penelitian ini menunjukan bahwa terdapat hubungan secara tidak langsung antara kompensasi melalui kepuasan kerja terhadap kinerja karyawan.

\section{Pengaruh motivasi kerja terhadap kinerja karyawan melalui kepuasan kerja}

Hasil penelitian menunjukkan motivasi kerja mempunyai pengaruh positif signifikan terhadap kinerja karyawan sehingga dapat dinyatakan bahwa motivasi kerja berpengaruh positif signifikan terhadap kinerja karyawan dengan kepuasan kerja sebagai variabel intervening sehingga hipotesis diterima. Hubungan motivasi kerja terhadap kinerja karyawan yang dimediasi oleh kepuasan kerja dinyatakan signifikan, hal ini juga berarti bahwa kepuasan kerja berperan sebagai partial control dalam hubungan motivasi kerja terhadap kinerja karyawan.

Pemberian motivasi kerja melalui pemberian penghargaan bagi karyawan yang berprestasi, dan menciptakan lingkungan kerja yang nyaman serta kondusif akan membuat karyawan merasa puas dalam bekerja, kemudian kepuasan yang diperoleh tersebut membuat karyawan untuk lebih terpacu untuk lebih disiplin, lebih berkualitas dalam bekerja, lebih teliti dan berusaha untuk bisa bekerja sama dengan rekan kerja lainya. Sehingga untuk memperoleh kinerja karyawan yang maksimal perusahaan harus bisa mencapai kepuasan kerja karyawan melalui pemberian motivasi kerja yang baik. 
Penelitian ini sejalan dengan penelitian (Nitasari \& Lataruva, 2012) yang menyatakan kepuasan kerja mampu menjadi variabel intervening dari hasil perhitungan standardized coefficients untuk pengaruh tidak tidak langsung motivasi kerja terhadap kinerja karyawan melalui kepuasan kerja lebih besar dibanding pengaruh secara langsung motivasi kerja terhadap kinerja karyawan.

\section{KESIMPULAN DAN SARAN}

\section{Simpulan}

1. Kompensasi berpengaruh positif signifikan terhadap kepuasan kerja, adanya pemberian kompensasi yang sesuai akan dapat meningkatkan kepuasan kerja karyawan.

2. Motivasi kerja berpengaruh positif signifikan terhadap kepuasan kerja, motivasi yang diberikan perusahaan dapat memberikan kepuasan kerja pada karyawan.

3. Kompensasi tidak berpengaruh terhadap kinerja karyawan, perusahaan sudah memenuhi kewajiban untuk memberikan kompensasi yang sesuai namun masih banyak karyawan yang mengeluh terhadap pekerjaan yang diberikan dan masih terdapat karyawan yang belum mampu melakukan kerjasama dengan rekan kerja lainya.

4. Motivasi kerja tidak berpengaruh terhadap kinerja karyawan, hal ini dikarenakan motivasi kerja yang diberikan belum sesuai dengan kebutuhan karyawan.

5. Kepuasan kerja berpengaruh positif signifikan terhadap kinerja karyawan, karyawan merasa puas terhadap hasil kerja yang dilakukan.

6. Kompensasi berpengaruh positif terhadap kinerja karyawan melalui kepuasan kerja karyawan, hal ini dikarenakan kompensasi tidak bisa membawa dampak langsung terhadap kinerja karyawan, namun kompensasi akan membawa dampak atau pengaruh langsung terhadap kepuasan kerja sehingga dapat meningkatkan kinerja karyawan.

7. Motivasi kerja berpengaruh positif signifikan terhadap kinerja karyawan melalui kepuasan kerja karyawan. Hal ini dikarenakan motivasi kerja tidak bisa membawa dampak langsung terhadap kinerja karyawan, namun motivasi kerja akan membawa dampak atau pengaruh langsung terhadap kepuasan kerja. 


\section{Saaran}

1. Perusahaan diharapakan memberikan kompensasi secara adil dan sesuai dengan pekerjaan yang diberikan, agar karyawan memperoleh kepuasan kerja sehingga dapat meningkatkan produktivitasnya, lebih disiplin, dan lebih teliti sehingga dapat mengurangi kesalahan dalam produksi.

2. Perusahaan diharapkan dapat memberikan motivasi kerja yang lebih sesuai kebutuhan karyawan serta melakukan pengawasan yang berkelanjutan terhadap kinerja karyawan agar perusahaan bisa mendorong para karyawan untuk lebih semangat bekerja. Dengan adanya semangat kerja yang baik maka karyawan akan memperoleh kepuasan dalam bekerja dan kepuasan terhadap hasil yang dikerjakan sehingga dapat meningkatkan kinerja karyawan.

\section{DAFTAR PUSTAKA}

Amianti, I., \& Supriyanto. (2012). Pengaruh Motivasi Kerja terhadap Kinerja Karyawan Bagian Marketing Bank Syariah: Studi kasus Pada karyawan PT BPRS Pemerintah Kota Bekasi. Maslahah-Jurnal Hukum Islam dan Perbankkan Syariah, 3(1), 174-180.

Bangun, W. (2012). Manajemen Sumber Daya Manusia, Erlangga, Bandung. Jakarta: Erlangga.

Bawoleh, V., Sifrid, S., Pangemanan, M., \& Tielung, V. (2015). The Effect of Motivation and Compensation toward Job Satisfaction in PT. Sig Asia Bitung. Jurnal Ekonomi, Manajemen, Bisnis dan Akuntansi (EMBA), 3(3), 472-481.

Damayanti, A. P., Susilaningsih, \& Sumaryati, S. (2013). Pengaruh Kompensasi dan Motivasi Kerja Terhadap Kinerja Karyawan Perusahaan Daerah Air Minum (PDAM) Surakarta. JUPE-Jurnal Pendidikan Ekonomi, 2(2).

Foster, B. (2011). Pembinaan untuk Peningkatan Kinerja Karyawan. Jakarta: PPM.

Garson, D. D. (2016). Partial Least Squares: Regression and Structural Equation Models.Asheboro . Nort Country: Statistical Associates Publishers.tam.

Hameed, A., Ramzan, M., Zubair, H., Ali, G., \& Arslan, M. (214). Impact of Compensation on Employee Performace (Empirical Evidence from Banking Sector of Pakistan). International Journal of Business and Social Science, 5(2), 302-309.

Handoko, H. T. (2014). Manajemen Sumber Daya Manusia. Yogyakarta: BPFE.

Hasibuan, S. (2016). Manajemen Sumber Daya Manusia. Jakarta: Bumi Aksara.

Hasibuan, S. P. (2014). Manajemen Sumber Daya Manusia. Yogyakarta: BPFE UGM.

Komara, A. T., \& Nelliwati, E. (2014). Pengaruh Kompensasi, Motivasi, dan Kepuasan Kerja terhadap Kinerja Pegawai Negeri Sipil (PNS) di Lingkungan Rumah Sakit Umum Daerah (RSUD) Kota Bandung. Jurnal Ekonomi, Bisnis \& Entrepreneurship, 8(2), 73-85.

Lusiana, I., Anggraini, K. S., \& Arina, F. (2015). Pengaruh Kompensasi Terhadap 
Kinerja Karyawan Melalui Motivasi Kerja dan Kepuasan Kerja Sebagai Variabel Intervening Menggunakan Structural Equation Modeling (SEM) (Studi Kasus di Divisi Produksi PT. XYZ). JTI: Jurnal Teknik Industri, 3(1), 1-8.

Maheswari, H., \& Lutvy, L. R. (2015). Pengaruh Kompensasi dan Motivasi Terhadao Kinerja Karyawan PT Bank Ekonomi Raharja Tbk Area Jakarta 5. Jurnal Manajemen, 19(2), 230-248.

Murti, H., \& Srimulyani, V. A. (2013). Pengaruh Motivasi Terhadap Kinerja Pegawai Dengan Variabel Pemediasi Kepuasaan Kerja Pada PDAM Kota Madiun. Jurnal Riset Manajemen dan Akuntansi (JRMA), 1(1), 10-17.

Nitasari, R. A., \& Lataruva, E. (2012). Analisis Pengaruh Motivasi Kerja terhadap Kinerja Karyawan dengan Kepuasan Kerja sebagai Variabel Intevening Pada PT. Bank Central Asia Tbk. Cabang Kudus. Diponegoro Journal of Management, 1(2), 446=454.

Puspitasari, F. A., Nursyamsi, I., \& Rasjid , W. (2018). Pengaruh Kompensasi, Kepemimpinan Transformasional, dan Komitmen Organisasi Terhadap Kinerja Karyawan Melalui Kepusan Kerja. Hasanuddin Journal of Applied Business and Entrepreneurship, 1(3), 51-67.

Racmawai, I. K. (2012). Manajemen Sumber Daya Manusia. Yogyakarta: Rineka Cipta.

Rivai, V., \& Sagala, E. J. (2011). Manajemen Sumber Daya Manusia untuk Perusahaan, dari Teori ke Praktik. Jakarta: PT Rajagrafindo Persada.

Riyadi, S. (2011). Pengaruh Kompensasi Finansial, Gaya Kepemimpinan, dan Motivasi Kerja Terhadap Kinerja Karyawan pada Perusahaan Manufaktur di Jawa Timur. Jurnal Manajemen dan Kewirausahaan, 13(1), 40-45.

Seniwoliba, A. J., \& Nchorbuno, A. D. (2013). Examining the role of motivation on employee performance in the public sector in Ghana. Merit Research Journal of Education and Review, 1(10), 227-249.

Soebroto, E. (2009). Entrepreneurship Menjadi Pembisnis Ulung. Jakarta: PT. Elex Media Komputindo.

Supatmi, M. E., Nimran, U., \& Utami, H. N. (2013). Pengaruh Pelatihan, Kompensasi terhadap Kepuasan Kerja Karyawan dan Kinerja Karyawan. PROFIT: Jurnal Administrasi Bisnis, 7(1), 25-37.

Supriyadi, H. (2015). Manajemen Sumber Daya Manusia: Menciptakan Keunggulan Bersaing Berbasis Kompetensi SDM. Yogyakarta: Andi.

Sutrisno, E. (2016). Manajemen Sumber Daya Manusia. Jakarta: Kencana Prenada. Media Group.

Swasto, B. (2011). Manajemen Sumber Daya Manusia. Malang: UB Press. 